https://helda.helsinki.fi

\title{
The Problem of Evil and the Grammar of God
}

\section{Koistinen, Timo}

2017-09

Koistinen , T 2017 , ' The Problem of Evil and the Grammar of God ' , Neue Zeitschrift für

systematische Theologie und Religionsphilosophie. , vol. 59 , no. 3 , pp. 394-409 . https://doi.org/10.1515/nzsth-201

http://hdl.handle.net/10138/243957

https://doi.org/10.1515/nzsth-2017-0021

unspecified

publishedVersion

Downloaded from Helda, University of Helsinki institutional repository.

This is an electronic reprint of the original article.

This reprint may differ from the original in pagination and typographic detail.

Please cite the original version. 


\title{
Timo Koistinen*
}

\section{The problem of evil and the grammar of God}

\author{
https://doi.org/10.1515/nzsth-2017-0021
}

Summary: In the contemporary Anglo-American philosophy of religion the problem of evil is one of the most widely discussed questions. In the context of these discussions, many prominent philosophers of religion have tried to offer a plausible - or, at least, a possible - explanation why an omnipotent and perfectly good being allows evil in the world and is also morally justified in doing that. There are also philosophers and theologians who think that this way of thinking is seriously misguided. In my paper I will deal with some ethical, theological/ metaphysical and meta-philosophical arguments that have been offered against conceptual frameworks used in the discussion of theodicy. In particular, I will pay attention to affinities and differences between the ways D. Z. Phillips and Brian Davies have criticized contemporary forms of theodicy. I will also analyse the relation between their thought by taking up the question of the nature and aim of philosophy of religion.

Keywords: theism, problem of evil, nature of philosophy, D. Z. Phillips, Brian Davies

Zusammenfassung: In der zeitgenössischen anglo-amerikanischen Religionsphilosophie ist das Problem des Bösen eine der meist diskutierten Fragen. Im Rahmen dieser Diskussionen haben viele prominente Religionsphilosophen versucht, eine plausible - oder zumindest mögliche - Erklärung dafür vorzubringen, warum ein allmächtiges und vollkommen gutes Wesen das Böse in der Welt zulässt und warum dies auch moralisch gerechtfertigt ist. Es gibt aber auch Philosophen und Theologen, die meinen, dass diese Denkweise völlig falsch sei. In meiner Arbeit befasse ich mich mit einigen ethischen, theologischen/metaphysischen und metaphilosophischen Argumenten, die gegen die konzeptionellen Rahmenbedingungen in der Diskussion über die Theodizee vorgebracht worden sind. Insbesondere werde ich auf Ähnlichkeiten und Unterschiede zwischen den Weisen, wie D. Z. Phillips und Brian Davies die zeitgenössischen Formen der Theodizee kritisiert haben, aufmerksam machen. Ich werde auch die Beziehung zwi-

*Corresponding author: Timo Koistinen, Faculty of Theology, P. O. Box 4 (Vuorikatu 3), FIN-00014 University of Helsinki, Helsinki, E-Mail: timo.koistinen@helsinki.fi 
schen ihren Gedanken analysieren, indem ich die Frage nach der Natur und dem Ziel der Religionsphilosophie aufgreife.

Schlüsselwörter: Theismus, Problem des Bösen, Natur der Philosophie, D. Z. Phillips, Brian Davies

In her famous book Evil in Modern Thought (2002) Susan Neiman argues that the question of theodicy has guided modern philosophy. According to Neiman, the problem of evil was a major theme in 18th and 19th century philosophy. In the $20^{\text {th }}$ century, philosophers' interests, however, changed. Philosophers in the Continental tradition retained some connection to the problem of evil, but philosophers in the analytic tradition have paid little attention to this problem. In this connection, Neiman notes that "contemporary analytic discussion of the problem of evil remains squarely confined to the marginalized field of philosophy of religion". ${ }^{1}$ As is well known, the problem of evil has indeed been one of the most widely discussed questions in this field, especially among the current that may be called analytic theism.

In this context, the problem of evil is treated as an argument against the existence of God. The debate typically starts from certain shared assumptions adopted in both theistic and atheistic philosophy of religion. Many philosophers, following J. L. Mackie, have formulated the problem of evil by referring to three propositions:

1. God is omnipotent.

2. God is wholly good.

3. Evil exists.

In his article "Evil and Omnipotence", Mackie argued that there seems to be a contradiction between these propositions, which, in his view, "are essential parts of most theological positions". ${ }^{2}$ So, it is inconsistent to accept all three propositions at the same time. This argument against theism is called "the logical problem of evil". In contemporary discussion it is often contrasted with "the evidential problem of evil", according to which, the existence of evil, e.g., the existence of actual human and animal sufferings, counts against the truth of

1 Susan Neiman, Evil in Modern Thought: An Alternative History of Philosophy (Princeton: Princeton University Press, 2002), 290.

2 J. L. Mackie, "Evil and Omnipotence," in The Problem of Evil, ed. by Marilyn McCord Adams/ Robert Merrihew Adams (New York: Oxford University Press, 1990), 25. This article was first published in Mind 64 (1955), 200-212. 
theism and makes it improbable, even if there is no obvious logical contradiction between propositions (1)-(3).

The term "theodicy" refers to any attempts to explain why an omnipotent and perfectly good God permits evil. Theodicy is a theoretical, speculative attempt to give an actual or possible reason God may have for allowing the existence of evil, or, at least, it is an attempt to give a reason, as Stephen Wykstra has done, why a theist may rationally believe that an infinite God has such a reason, although we as finite human beings do not know what this reason is. ${ }^{3}$

In what follows, I will not pay attention to current debates among those analytic theists who have attempted to give an actual or possible reason why God allows evil. Instead, the central aim is to analyse approaches in which it is argued that this discussion is fundamentally confused. The word "antitheodicy" refers to a view which rejects the efforts to justify or explain the existence of evil. An antitheodicist thinks that the way in which analytic philosophers usually deal with the problem of evil - their whole way thinking about this matter - is seriously wrong. An antitheodicist rejects the fundamental presuppositions and conceptual parameters that guide theodicies. In recent decades, philosophers and theologians, such as D. Z. Phillips, Terrence Tilley, Kenneth Surin, John Roth and Andrew Gleeson, have offered various kinds of ethical, theological and metaphilosophical criticisms against the conceptual frameworks used in the contemporary analytic discussion of theodicy. ${ }^{4}$

I will not offer a survey of all thinkers and approaches in the antitheodicist tradition. Instead, I will discuss two different approaches in the criticism of theodicies. First, I will deal with Brian Davies, whose arguments have been much influenced by the Thomistic tradition. I am not sure whether "antitheodicy" is the best label in Davies' case, but he does offer very strong criticism of contemporary theodicies. After that I will deal with D. Z. Phillips' views of the matter. What I find interesting is that although these two philosophers come from very different philosophical traditions, they nevertheless share some critical insights. Both of them think that a central problem in contemporary discussion is a mistaken and confused conception of God. The conception of God is at the heart of the debate on the problem of evil, and typically analytic philosophers simply take for granted assumptions Davies and Phillips find questionable. Their criticism of a contempor-

3 See Stephen J. Wyкstra, "The Humean Obstacle to Evidential Arguments from Suffering: On Avoiding the Evils of 'Appearance'," in International Journal for Philosophy of Religion 16 (1984), 73-93.

4 For a useful account of antitheodicy, see N. N. Trakakis, "Antitheodicy," in The Blackwell Companion to the Problem of Evil, ed. by Justin P. McBrayer/Daniel Howard-SNyder (Wiley Blackwell: Oxford, 2013). 
ary form of theism touches not only upon the basic assumptions of the debate, but their objection to a generally accepted framework in the debate of the problem of evil also has considerable implications for the general methodological starting points of philosophy of religion. In this respect, there are, however, significant differences between Davies' and Phillips' approaches. In the last section I will analyse the relation between Davies' and Phillips' thought by taking up the question of the nature and aim of philosophy of religion.

\section{Thomistic objection to theodicy}

Davies' criticism of contemporary forms of theodicies is based on classical theological and metaphysical insights on the doctrine of God. He argues that many prominent contemporary analytic philosophers of religion, such as Alvin Plantinga, Richard Swinburne, Stephen T. Davis, and William Hasker, have developed and defended a version of theism that Davies calls "theistic personalism". This version of theism differs radically from what he calls "classical theism" - a view represented by influential Christian, Jewish and Muslim theologians, such as St. Augustine, Thomas Aquinas, Avicenna, Moses Maimonides, as well as many Protestant theologians. ${ }^{5}$

Theistic personalism is based on the idea that God is a person, and the concept of person, in turn, is explained by referring to characteristics of human persons. Richard Swinburne, for example, who is a prominent advocate of theistic personalism, characterizes God as "a person without body". ${ }^{6}$ Swinburne as an advocate of substance dualism defends the view that human beings are composed of both a material body and an immaterial consciousness. He thinks that God, unlike human beings, is not material and does not have a body, but like human beings God has consciousness or a mind. In that respect God is like us, and thus Swinburne thinks that God and human beings belong to the same class, i.e., to the class of persons. ${ }^{7}$ According to Swinburne, human beings can conceive, at least partly, what God is like. The way we conceptualize human action and thought can be applied to God's action and thought. In Swinburne's view, we can have a fair understanding of what it is like to be omnipotent and immaterial spirit, who is capable of thinking and wanting, and who has a strange power to do things in the material world. ${ }^{8}$

5 Brian Davies, “A Letter from America,” in New Blackfriars 84 (2003), 371-384, here: 380.

6 Richard Swinburne, The Coherence of Theism, revised edition (Oxford: Clarendon Press, 1993), 1.

7 Brian Davies, The Reality of God and the Problem of Evil (London: Continuum, 2006), 52.

8 Swinburne writes: "Imagine yourself, for example, gradually ceasing to be affected by alcohol or drugs, your thinking being equally coherent however men mess about with your brain. Imagine 
Theistic personalism is typically associated with a literal or univocal understanding of religious language. Talk about God's personhood, attributes and actions does not differ radically from talk about the attributes and actions of human beings. God has no body, but his "knowledge" and "power" are conceived as human-like attributes. Thus, although God's knowledge and power are without the limitations of finite human beings, words describing the attributes and actions of God mean the same thing as when they are applied to human beings. Along these lines, contemporary advocates of theistic personalism deny some classical views of God. There are different views among theistic personalists on the doctrine of God, but one can say that they typically deny the classical doctrine that God is an immutable being outside of time. Instead, God is understood as an eternal being, who has always been and always will be, but who exists inside of time. Some theistic personalists, such as William Hasker, have even suggested that God changes and learns new things. According to Hasker's "open theism", God, in creating the world, takes a risk. God's omniscience is restricted by time, i.e., God does not know what will happen in the future. Therefore, one cannot blame God for what free creatures' future choices will be. ${ }^{9}$

Davies contrasts classical theism strongly with theistic personalism. Classical theism does not start from the anthropomorphic idea that God is a person like us. Instead, it stresses the radical difference between God and creatures. God is essentially the Creator of everything that exists. Davies explains the concept of God in terms of an answer to the ultimate metaphysical question "Why is there something rather than nothing?" or "Why does anything exist at all?" The ultimate question expresses a deep mystery of being, and God is a mysterious

too that you cease to feel any pains, aches, thrills, although you remain aware of what is going on in what has been called your body. You gradually find yourself aware of what is going on in bodies other than your own and other material objects at any place in space ... . You also come to see things from any point of view which you choose, possibly simultaneously, possibly not. You remain able to talk and wave your hands about, but find yourself able to move directly anything which you choose, including the hands of other people ... . You also find yourself able to utter words which can be heard anywhere, without moving material objects. However, although you find yourself gaining these strange powers, you remain otherwise the same - capable of thinking, reasoning, and wanting, hoping and fearing ... . Surely anyone can thus conceive of himself becoming an omnipresent spirit." Swinburne (see above, n. 6), 107. Quoted from Davies, The Reality (see above, n. 7), 52-53. In contrast to what Swinburne assumes, Davies finds Swinburne's thought experiment wholly inconceivable. Davies, The Reality (see above, n. 7), 53.

9 William Hasker, God, Time, and Knowledge (Ithaca and London: Cornell University Press, 1989); Davies, A Letter (see above, n. 10), 377-380. 
(non-scientific) answer to this question: God is the cause of all existent entities. Everything that exists is absolutely dependent on God. ${ }^{10}$

The classical doctrine of divine simplicity is a central part of classical theism, and it plays an important role in explaining the difference between the Creator and creatures. This doctrine teaches that the Creator God is unique, God has no parts, and is wholly unlike other beings. The Creator is not a being among beings but, as Aquinas said, Ipsum Esse Subsistens, Subsistent Being Itself. According to Aquinas, God creates the world ex nihilo, which means that God accounts for the existence (esse) of everything within the world, and therefore one can say that God exists outside the realm of existent beings. The existence of God does not derive from something other than God - there is no distinction between God's essence and God's existence - i.e., in God essence and existence are identical. The radical difference between Creator and creatures is also present in Aquinas' view of God's properties. As is well known, Aquinas thought that theological predication differs from the kind of predication we use in other contexts. "God is good" and "God is just" do not mean that God has certain properties (goodness and justness) distinguishable from himself. Instead, God's properties and God himself are not distinguishable, i.e., there is no distinction between God and his properties. Thus, God does not have a property called goodness, but God is goodness. Furthermore, Aquinas thought that God is unlike individual beings in the world which can be classified and can belong to kinds. God is not a member of a kind, which implies among other things that God is not a person like us, i.e., God is not an instance of a kind that we call persons. ${ }^{11}$ Put briefly, God is radically different from that we are familiar with in the created world. Because of this uniqueness and strangeness of God, descriptive categories we use in speaking about created things cannot be applied to God. Davies stresses that there is a close connection between classical theism and the tradition of negative theology. ${ }^{12}$

Davies notes that theistic personalism takes for granted the idea that "God is good", and this means that "God is morally good”. In other words, God is treated

10 Davies, A Letter (see above, n. 10), 373-375; Davies, The Reality (see above, n. 7), chapter 2.

11 Davies notes that the formula "God is a person" is a recent one in the history of theology. He tells that the first occurrence of this formulation in English comes from the report of a trial in 1644. In this trial, a Unitarian called John Biddle was accused of heresy, for he had claimed that "God is a person". Davies points out that this formulation differs from the classical Trinitarian formulations. In addition, the Cartesian conception of a human person as an incorporeal thinking substance is not what a "person" meant in Trinitarian discussions. Brian DAvies, "Is God a Moral Agent?," in Whose God? Which Tradition? The Nature of Belief in God, ed. by D. Z. PHILLIPS (Aldershot: Ashgate, 2008), 113.

12 Davies, The Reality (see above, n. 7), chapter 3. 
as a member of a moral community. God is understood as a moral agent who is subject to the same moral requirements as we are. Swinburne, for example, thinks that God is a subject of duties and obligations. He thinks that "God is by nature perfectly morally good" and "perfect moral goodness includes doing both the obligatory and supererogatory and doing nothing wrong and bad in other ways ... . Perfect moral goodness surely involves fulfilling one's moral obligations." ${ }^{13}$ In the light of classical theism, this does not make sense. God, who is a timeless and immutable source of reality is not subject of any obligations or duties. Things that can be said about moral agents cannot be said of the Creator. The idea of God as "an invisible person anxious to do what it is right for him to do" goes badly astray. God cannot "be sensibly thought of as either guilty or exonerable by human standards". ${ }^{14}$ God cannot be thought of, for example, as someone who has vices and virtues or as someone who behaves well or badly. In the light of Thomistic thought we can, however, say that God is good, but God's goodness is not moral goodness, for that is a property of human beings. According to classical theism, talk about God is goodness refers to his perfection of being; he is the source of being and the goodness of things. In this respect, God can be depicted as good, but this does not mean that God is wellbehaved by human standards. It makes no sense to assume, as many philosophers of religion seem to do, that the source of being owes us a moral explanation. In that sense, classical theism does not have the problem of evil. ${ }^{15}$

\section{A Wittgensteinian objection to theodicy}

Phillips attacks the contemporary discussion of the problem of evil on various grounds, appealing to ethical, religious and meta-philosophical insights. ${ }^{16}$

One of the major problems with this discussion is, according to Phillips, the consequentialist approach to moral issues. Contemporary theodicies typically argue that in allowing human and animal suffering God brings about some greater good that compensates for evil. In addition, it is assumed that God cannot bring about that the greater good without allowing evil: in this respect, evil is a

13 Swinburne(see above, n. 6), 184-185; Davies, Is God (see above, n. 11), 102.

14 Davies, The Reality (see above, n. 7), 253.

15 Brian Davies, An Introduction to the Philosophy of Religion (Oxford: Oxford University Press, 2004), 215-216; 226-231; DAVIES, The Reality (see above, n. 7), chapter 4.

16 Phillips has dealt with the problem of evil in many of his works. His most systematic treatment of this topic is D. Z. Phillips, The Problem of Evil and the Problem of God (London: SCM Press, 2004). 
necessary element in the created world. Therefore, one can say that there is no such thing as pointless evil.

Phillips finds absurd the attempt to seek the morally sufficient reasons God has or may have for allowing evils, and especially such horrors as the Holocaust. In Part One of his book, The Problem of Evil and the Problem of God, he criticizes various kinds of efforts in analytic philosophy of religion to show that there are greater goods that justify the presence of evil in the world. Phillips' criticism against contemporary theodicies and defences ${ }^{17}$ - developed by, e.g. Swinburne, Hick, Plantinga, Stephen T. Davis - takes different forms.

One line of Phillips' criticism is directed against the way moral concepts are used in contemporary theodicies, namely contemporary theodicies do not do justice to ordinary demands of morality. For example, it does not make sense to appeal to the idea that moral responsibility - the ability to develop spiritually and morally - given by God is an extremely valuable thing that justifies suffering. ${ }^{18}$ According to Phillips, this way of thinking distorts our moral relations to the suffering of others: the suffering of others cannot be seen as an opportunity for our moral development. Furthermore, Phillips argues that it does not make much sense to speak about a person's own suffering, in general, as the possibility of developing oneself morally. Although in some particular cases this kind of talk might be sensible, my own suffering obviously does not always promote my moral growth. Phillips also points out that our own suffering is often caused by what happens to others. Thus, for example, it would be strange to say that the death of a child is justified, because the suffering of parents gives them an opportunity to develop their character. According to Phillips, the instrumentalist way of speaking about these matters is not only innocent speculation, it is a trivialization of human suffering in death camps. To suppose - even in philosophical discussion that the Holocaust is connected to some greater good is morally offensive. Phillips thinks that the weakness of the theodicists' arguments is also shown by the fact that when they are not doing philosophy, they do not speak about horrendous evils in the same way that they speak about them in developing their theories. ${ }^{19}$

17 Alvin Plantinga makes a distinction between theodicies and defences. A defence is weaker form of apology than a theodicy. It does not try to offer an answer why God permits evil. Instead, it is an effort to show that it is logically possible that a perfectly good, omnipotent and omniscient God creates a world that contains evil. Plantinga argues that a world containing free creatures is more valuable than a world containing no free creatures. This offers a possible explanation for God to allow evil. See, e.g., Alvin Plantinga, God, Freedom, and Evil (London: Harper \& Row, 1974).

18 Philuips, The Problem of God (see above, n. 16), chapter 3.

19 Phillips, The Problem of God (see above, n. 16), 38-40. 
Phillips appeals here to what we know about moral matters: in the light of our ordinary ethical parameters it is undeniable that death camps are pointless and unjustified. The speculation about God's hidden reasons that serve some good divine purpose leads to radical moral scepticism: appealing to our ignorance of divine purposes does not make sense at all.

Another line of Phillips' criticism, which is closely tied to the moral criticism of theodicies, is directed at the way the concept of God is analysed in this discussion. Like Davies, he rejects the anthropomorphic concept of God adopted by analytic theists. It is misleading to treat God as a moral person whose actions can be subject to our moral judgments. God is a not being among beings and not a moral agent among moral agents. It is not intelligible, for example, to speak about God's covenant with his people as a contract in which God stands "in reciprocal relations of rights and obligations to the other parties to the contract". It makes no sense to think of God as "part of a community of criticism and countercriticism”, as theodicists do. ${ }^{20}$

In The Problem of Evil and the Problem of God Phillips argues at length that theodicies are based on confused ways of speaking about God's power and goodness. When God is identified with the anthropomorphic conception of a morally perfect being, apologetic theism meets severe difficulties linked with the effort to show that this agent has or might have morally acceptable reasons for his doings. Phillips illuminates these difficulties by referring to an example from William Styron's novel Sophie's Choice. ${ }^{21}$ In this fictional story a Polish survivor of Auschwitz, Sophie Zawistowska, a mother of two children, Eva and Jan, is forced at the gates to Auschwitz by an SS official to choose life for one of her children and death in the gas chamber for the other. In this extremely dark situation, Sophie screams "I cannot choose", but she lets Eva go. The story continues gloomily. Eva dies in a gas chamber and Sophie never gets to know what happened to Jan. Sophie cannot live with her decision and kills herself after the war. In considering the story, Phillips notes that we cannot, of course, condemn Sophie from the third person's perspective. For outsiders, the proper attitudes for her are pity and compassion. However, things look different from Sophie's own perspective: her decision has stayed with him. "She is involved in a moral tragedy, where, whatever she did, would involve evil". Phillips says that "Sophie never thinks of handing Eva over as an act to be excused in the light of the total situation."22 Now,

20 Phillips, The Problem of God (see above, n. 16), 148-151.

21 Phillips borrows this story from John Roth, who uses it in developing his "theodicy of protest". John K. Rотн, “A Theodicy of Protest,” in Encountering Evil, ed. by Stephen T. DAvis (London: Westminster John Knox Press, 2011).

22 Phillips, The Problem of God (see above, n. 16), 42. 
Phillips argues that under the assumptions of analytic theism, God is seen to be a member of a moral community, and in this sense is like Sophie. As a moral agent he has allowed horrible things such as the Holocaust to happen, and according to theodicies and defences he has morally sufficient reasons for that. In the light of the parallel between Sophie's case and God, the talk about God's perfect goodness appears strange. Phillips asks:

Is God to be the object of pity? Is creation a moral tragedy in which God is necessarily involved in evil? And what of God's view of what he has done? Does the Holocaust stay with him? Does he think that it can be excused in the light of the greater good that made it necessary, or does he recognize he has something to answer for? It will be obvious that within these moral parameters, there is no logical space for talk about God's perfect goodness. $^{23}$

Phillips notes that we are all familiar with situations in which there are only bad alternatives. If God is seen as a member of a moral community which has allowed the Holocaust to exist, the talk about God as a morally perfect being makes no sense.

The criticism of philosophical abstractions plays a central role in Phillips' criticism of analytic theism. He finds the common way of defining divine omnipotence as too general to be meaningful. In contemporary discussions, this concept is typically defined in an extremely abstract way, i.e. in a way that is independent of the concept of God. For example, Swinburne says that "An omnipotent being is one who can do anything logically possible." ${ }^{24}$ Phillips argues that these kinds of abstract definitions are inaccurate, for there are obviously plenty of things God cannot do. To use his own examples: God cannot ride a bicycle or eat ice-cream. God - or perhaps one should add: the first person of the Trinity - who is spirit, cannot do these kinds of things. Phillips' basic point is that it makes no sense to treat the term "omnipotence" as if it had a meaning outside the context of its religious use, or to put it in another way, it makes no sense to ascribe "all power" to God, because the term "power" means different things in different contexts. Phillips stresses that God's power is a special kind of power. It is not the power of the dictator or the devil: it is not the ability to do anything that someone just happens to want to do. Instead, God's power is the power of love. Thus, the anthropomorphic understanding of God's properties is misplaced.

23 Phillips, The Problem of God (see above, n. 16), 43.

24 Richard Swinburne, Providence and the Problem of Evil (Oxford: Clarendon Press, 1998), 3; quoted in Phillips, The Problem of God (see above, n. 16), 6. 
In certain respects, Phillips' thought comes close to the classical doctrine of God's simplicity. Phillips says that "God does not have two separate attributes, power and love, but that the only power God has or is, is the power of love". ${ }^{25}$ Like Davies, Phillips holds that the subject-predicate distinction does not apply to God. In describing a human person we can make a distinction between a person and his contingent properties. A person may or may not be loving or red-haired, etc., but in the case of God "goodness" and "love" are God's "grammatical predicates", which are not "related contingently to 'God', but are instances of what the word 'God' means". ${ }^{26}$ As Rush Rhees puts it, "Winston Churchill may be Prime Minister and also a company director, but I might come to know him without knowing this. But I could not know God without knowing that he was the Creator and Father of all things." ${ }^{27}$ Similarly, one cannot know God without knowing that God is love. Thus, the understanding of God as a kind of limitlessly powerful Being who may cause or bring about any logically possible state of affairs is misplaced.

\section{Metaphysics and the grammar of God}

We have seen that there are considerable similarities between Phillips' and Davies' criticisms of theodicies, but there are also important differences between them. Davies is critical towards Phillips' descriptive grammatical approach to the philosophy of religion. Davies claims that there is no such thing as "the grammar of God". ${ }^{28}$ Instead, he prefers to think that there are different conceptions of God and one task of philosophy is to provide arguments for them. Like Aquinas, he thinks that by appealing to purely philosophical reflection one may rationally argue that God exists and present arguments what this belief amounts to and what it does not amount to. Phillips, in turn, thinks that it is not the task of the philosopher to provide arguments for or against the existence of God. Instead, the task of the philosopher, in general, is to look at the way concepts are used in various contexts of our lives. The task of the Wittgensteinian philosophy of religion is not to offer answers and solutions to people's religious questions, but to try to understand the meaning of these questions and show

25 Phillips, The Problem of God (see above, n. 16), 199.

26 Phillips, The Problem of God (see above, n. 16), 188.

27 Rush Rhees, Rush Rhees on Religion and Philosophy, ed. by D. Z. Phillips (Cambridge: Cambridge University Press, 1997), 48; quoted in Phillips, The Problem of God (see above, n. 16), 189.

28 Davies, Is God (see above, n. 11), 97. 
the variety of religious possibilities. ${ }^{29}$ Philosophy aims at clarification of meaning; it is not a handmaid of religious or atheistic apologetics. This does not mean that there is no normative aspect in philosophy. One of philosophy's central tasks is to clarify conceptual confusions in the ways philosophers speak about reality. But in doing that, a Wittgensteinian philosopher does not offer any kinds of theories, explanations or new knowledge about reality. In appealing to the logic of our religious language a philosopher appeals to actual practices and grammatical rules present in our ways of speaking. Thus, the notion of "philosophical description" or "philosophical account" has a special meaning in Wittgensteinian philosophy. Philosophical descriptions or accounts are not theoretical or metaphysical explanations of the meaning of religious practices and beliefs. Philosophical, i.e., grammatical, descriptions are not theories at all: the notion of 'description' in Wittgenstein's thought is contrasted with theories and explanations. When a philosopher gives a perspicuous representation of religious practices and beliefs by showing their grammar, he or she does not offer new or hidden information about religious realities. As Wittgenstein says, in giving an account of a use of a word, a philosopher looks at things that lie "open to view". ${ }^{30}$ In giving an account of religion a philosopher appeals to what we are already familiar with, i.e., the ordinary or normal uses of language.

Phillips does not, of course, deny that there are genuine, meaningful and unconfused disagreements concerning religion. But the task of philosophical investigation is not, according to Phillips, to solve religious disagreements, but to clarify conceptual confusions concerning religion, and a philosopher may do this without accepting a certain form of religious belief. Phillips rejects rationalism or evidentialism, according to which philosophy aims to show which worldview is true (or probably true) by appealing to arguments based on universal and neutral reasons. He also rejects reformed epistemology's "particularistic perspectivism" that tries to show that a religious person may regard his beliefs a reasonable without (universally accepted) evidence. Wittgenstein's and Phillips' philosophical interests differ from interests of philosophical apologetics and religiously confessional philosophy. The presence of conceptual confusion is a starting point

29 D. Z. Phillips, Religion and the Hermeneutics of Contemplation(Cambridge: Cambridge University Press, 2001).

30 "Philosophy simply puts everything before us, and neither explains nor deduces anything.Since everything lies open to view there is nothing to explain. For what is hidden, for example, is of no interest to us." Ludwig Wittgenstein, Philosophical Investigations, transl. G. E. M. Anscombe, 3rd edn. (London: Basil Blackwell, 1972), 126§. 
of philosophical discussion: it is not matter of seeking evidence for religious world views. ${ }^{31}$

By contrast, Davies' approach, as mentioned, has an apologetic-normative dimension. He thinks that as a philosopher he must deal with questions concerning the truth, coherence and validity of different conceptions of God, and he defends classical theism by appealing to a version of the cosmological argument. ${ }^{32}$ In this light, it is curious that he thinks that Phillips' account of the concept of God reflects traditional teachings of God. He has argued that Phillips' non-anthropomorphic account of the concept is much more orthodox, i.e., closer to traditional views, than are accounts of advocates of theistic personalism, who have often criticized Phillips for distorting classical theological views. ${ }^{33}$

The relationships between these three approaches - Wittgensteinian, Thomistic and analytic theism - are complicated in many ways. Metaphysics - the study of ultimate reality - plays a central role in Thomism and analytic theism, but Phillips, following Wittgenstein, has provided radical criticism of metaphysics. The ultimate question connected with classical theism "Why is there something rather than nothing?" leads to a perspective that is foreign to Phillips' thought. Unlike metaphysicians, he does not speak about the belief in God in terms of a first cause, and he finds the idea of the world as a thing and the idea of "asking for the cause of everything" problematic. These terms are used in a contextless way in philosophical speculation and thus they are devoid of meaning. ${ }^{34}$

31 D. Z. Phillips, Religion and Friendly Fire. Examining Assumptions in Contemporary Philosophy of Religion (Aldershot: Ashgate, 2004), chapter 1.

32 Davies, The Reality (see above, n. 7), chapter 2.

33 Many philosophers have expressed doubts concerning the neutrality of Phillips' approach. It has been argued that Phillips is not actually describing traditional Christian beliefs, rather he is prescribing a certain revised form of Christianity, and therefore his account of religious beliefs really do not "leave everything as it is". See Timo Koistinen, "The Vantage Point of Disinterested Inquiry: On the Neutrality of D. Z. Phillips' Philosophy of Religion,” in Studia Theologica 66 (2012), 130-148. Davies partially disagrees with this accusation against Phillips. He refers to this theme in his article "A Letter from America”, in which he evaluated the conceptions of God in the thinking of contemporary American philosophers. He offers strong criticism of theistic personalism. He also names philosophers who, is his view, have a sound sense of God. Among them he mentions Phillips and some other Wittgensteinian philosophers. Davies, A Letter (see above, n. 10), 377. Phillips regarded Davies' critical comments on contemporary analytic philosophy of religion as remarkable. See D. Z. PhilLips, “God” and Grammar: An Introductory Invitation,” in Whose God? Which Tradition? The Nature of Belief in God, ed. by D. Z. PHillips (Aldershot: Ashgate, 2008).

34 Phillips, Religion and the Hermeneutics (see above, n. 29), 69. Davies, in contrast, finds ultimate metaphysical questions to be meaningful. In addition, his account of God's omnipotence 
Nevertheless, Thomism and analytic theism embody very different ideas about the metaphysics of theism. Classical theism is grounded in an AristotelianThomistic conceptual framework. It stresses the incomprehensibility of God, and in this respect it differs radically from personal theism. A crucial difference between classical and personal theism hasto do with the traditional problem of divine predication. Analytic theists, such as Swinburne and Hasker, advocate a univocal understanding of religious language, according to which the terms we use in speaking about creatures have the same sense when these are applied to God. When we say that God is a person, who wills and causes things to happen, we use these term broadly in the same way as we use them in speaking about human persons. Davies, in turn, following Aquinas, thinks that the words we use in talking about creatures do not have the same sense when we use these words about God. As is well known, Aquinas also rejects the equivocal predication of these terms, and he defends the doctrine of analogical predication, according to which terms which refer to divine perfections, e.g., goodness and wisdom, can be applied to God and creatures in the analogical sense in contrast to univocal and equivocal senses. Thus, “Aquinas thinks that, in some sense of 'same sense,' there are words that we can use when speaking of both God and creatures that bear the same sense". ${ }^{35}$ But this does not mean that we can know what God is. As mentioned above, in the light of the doctrine of divine simplicity the talk about

differs from Phillips'. Davies says that Phillips "appears to want to get rid of the notion of omnipotence altogether”. Brian Davies, “D. Z. Phillips on God and Evil," in Philosophical Investigations 35 (2012), 317-330, here: 321. Following Aquinas, he holds that God's omnipotence is a central element in the classical teaching of God, according to which God is omnipotent as the Creator. However, Davies notes that, according to Aquinas, God is not omnipotent, because he can do everything that created beings can do that - so Phillips is thus right in claiming that God cannot eat ice-cream, etc. But God, according to Aquinas, is omnipotent, because God as Creator can make exist anything that is "absolutely possible", i.e., anything that can consistently be said to be. IDEM, 319-320. In a critical review of Phillips' The Problem of Evil and the Problem of God William Hasker argued against Phillips' criticism of the way omnipotence is understood in analytic theism. Phillips responded to Hasker's review in an article that was published after Phillips' death. William Hasker, "D. Z. Phillips' Problems with Evil and with God," in International Journal for Philosophy of Religion 61 (2007), 151-160; D. Z. PHillips, "William Hasker's Avoidance of the Problems of Evil and God (or: on Looking Outside the Igloo)," in International Journal for Philosophy of Religion 62 (2007), 33-42. The discussion continued between Hasker and Andrew Gleeson, who defended and elaborated Phillips' arguments against omnipotence in terms of logical possibility. Andrew GleEson, "The Power of God," in Sophia 49 (2010), 603-616; Andrew Gleeson, "More on the Power of God: A Rejoinder to William Hasker," in Sophia 49 (2010), 617629; William HASKER, "Which God? What Power. A Response to Andrew H. Gleeson," in Sophia 49 (2010), 433-445.

35 Brian Davies, Thomas Aquinas on God and Evil (Oxford: Oxford University Press, 2011), 52. 
"God's properties" - which is common in contemporary theism - is misleading. God does not have "properties distinguishable from himself or distinguishable from each other". ${ }^{36}$ God's nature is incomprehensible and beyond the ordinary conceptual categories. Thus, although we can refer to God as good and wise (because God is the cause of goodness and wisdom in creatures) God is not good and wise in the same way in which creatures are good and wise. There is a radical grammatical difference between divine predication and conceptual categories of ordinary talk.

The difference between God and the world is a central doctrine in classical theism. However, although Phillips rejects metaphysics, he thinks that the notion of God's transcendence - i.e. the belief that God is other than the world has a role and meaning in religion, but he thinks that this notion should be brought back from metaphysics to its natural religious home. God's otherness from the world is "a spiritual otherness": "God is other than worldliness and egocentricity". ${ }^{37}$ God's reality is a spiritual reality. The transcendence of God should not be objectified in terms of metaphysical systems. In contrasts to Davies, Phillips uses the term 'world' in the biblical rather than in the metaphysical sense. There is no single univocal concept of the world, and philosophy does not offer general metaphysical theories of everything. God's reality is spiritual reality, and spiritual matters should not be approached by seeking some kind of non-scientific knowledge of the unobserved cause of the physical cosmos. Rush Rhees writes:

My point is that belief in a creator is not the belief in a cause, even in the special sense which Aristotle has in mind. The belief in a creator might go with the thought that 'There might never have been anything existing at all', or (as it has been expressed) 'Isn't it extraordinary that anything at all should exist.' If we call this an expression of wonder, then it is the same wonder as is expressed in 'This is all God's handiwork; this declares the glory of God', or -'This - that there should be anything at all - shows God's goodness.' ... it is not asking for an explanation, or even wondering what the explanation is..$^{38}$

Yet, it must be remembered that Davies makes a sharp distinction between scientific explanations and the ultimate explanation. According to his view, the existence of the universe is a mysterious riddle, and God is a mysterious answer to this riddle. Unlike scientific answers, God is not an explanation in a sense that

36 Davies (see above, n. 35), 53-54.

37 D. Z. Phillips, "Wittgenstein, Religion, and 'First Philosophy'," in Religion and the End of Metaphysics, ed. by D. Z. Phillips /Mario von der Ruhr (Tübingen: Mohr Siebeck, 2008), 43.

38 RheEs, Rush Rhees on (see above, n. 27), 4. I thank Tero Massa for drawing my attention to this remark. 
it is "something we understand better than that with respect to which we invoke it as an explanation". ${ }^{39}$ Following Aquinas, Davies thinks that the cause everything is something that we are unable to understand: the first cause is wholly unlike creaturely causes in the physical world. God's creative act is sui generis. The sense of mystery distinguishes Thomistic metaphysics of God from theistic personalism, according to which God is a person comparable to us and whose actions can be described as a human person's actions can be described. ${ }^{40}$

There are important and deep differences between Davies' Thomistic and Phillips' Wittgensteinian approaches. However, in the context of the contemporary debate on the problem of evil it is extremely intriguing that an adherent of the metaphysical philosophical tradition and an adherent of the anti-metaphysical philosophical tradition agree that there is something seriously wrong with contemporary forms of theodicy. Both of them think that the central problem in that discussion is a confused conception of God.

39 Brian Davies, “D. Z. Phillips on Belief in God,” in Philosophical Investigations 30 (2007), 219244, here: 236.

40 It is worth mentioning that Phillips also connects the religious mystery with "the sense of life as a mystery", with "our being creatures in space and time" and with "radical contingencies in human life". Phillips, Religion and Friendly Fire (see above n. 31), 49-50. It would be tempting to see here a connection with the ultimate question in classical theism as Davies develops it. However, Andrew Gleeson, whose thinking is heavily influenced by Phillips, distinguishes between "impersonal" (Davies, Herbert McCabe) and "personal understanding" (Phillips, Gleeson) of the ultimate question. When the ultimate question is understood as a personal question, it gets its sense from the religious and existential background and not from metaphysical speculation. It has to do with, e.g., a sense of the perishability of the world, our mortal existence and our capacity to see meaning in our lives. When one asks a personal question one does not "cry for information at all" and there is no single right answer to this question. Andrew GLEESON, "God and Evil: A View from Swansea," in Philosophical Investigations 35 (2012), 331-349, here: 344-345. See also Andrew Glemson, Frightening Love: Recasting the Problem of Evil (Houndmills, Basingstoke, Hampshire: Palgrave Macmillan, 2012). 